with the College and our increased credibility with the public and patients should all enable the storms that would blow following the Bristol Inquiry not to become a destructive hurricane.

\section{Users and carers groups}

During the year, the President had Chaired a Black/White User Committee. Initially they had met in a somewhat clandestine manner in the basement of the College; however, 2 weeks ago, the work of this group had achieved such prominence that we were on the search for more leaders of Black User Groups and this Working Group would, in future, be accountable to the new Ethnic Issues Committee. This development was potentially of the utmost importance as patients from Black and ethnic minorities were disadvantaged by a perceived gulf between their needs and the mental health services that were available. The Patients and Carers Committee, now a Special Committee of Council, would therefore become increasingly influential; why should they not contribute to the Court of Electors and to the Education and Examination Committees of the College?

Certainly, the boundaries between the Government and the medical professional were being redefined. Colleges who had jealously guarded their independence now had to accept much greater accountability to Parliament and the public. The President noted that, as psychiatrists, we knew that seeming opposites were the energy for creative endeavour, and that threats were spurs to action for wider links with other professionals, governments and user groups.

Professor Cox said that we had known, or should have known, from Maxwell Jones et al all about user involvement, multi-professional training and comprehensive care planning - but we had not had the resources and the back-up to deliver what we knew to be better management. The roles of consultant psychiatrists, including those with psychotherapy training, within multidisciplinary teams needed to be clarified. Medical psychotherapists were central to the culture of our profession.

\section{Conclusion}

The President said that his Report reflected his own opinions and his hopeful belief that those who worked in the mental health field in 5 years' time - and perhaps sooner - would see substantial improvements in recruitment and retention and in working conditions, including the appalling state of the acute in-patient wards. We might then gradually see a return to much greater job satisfaction than was at present the norm. CPD, the intellectual excitement of discovering new things, including why things went wrong, having responsibility with power and the ability to own and influence a budget could restore the self-confidence of welltrained consultant psychiatrists.

As he entered his third and final year as President, Professor Cox concluded by thanking members for their support and thanking Keele University and Combined Healthcare NHS Trust for 'seconding' him to the post.

He also expressed his thanks to his wife, Karin, and to his three daughters, who had seen them through some unexpected severe health problems, which had placed them on the receiving end of the NHS, and their resultant recognition of the benefits of skilled tertiary, secondary and primary care services. The learning curve was steep; the suffering real and yet the care and cure miraculous.

Professor Cox suspected that by the end of the AGM on Friday, and certainly by Saturday, the College staff would need and deserve a holiday, and that the College as well as the WPA would by then have changed a little for the benefit of our patients and for the good of all.

The Winged Cross, the Egyptian Ankh, as a symbol of Hope on the College crest was surely an imaginative act of heraldry. When 30 years ago the Royal MedicoPsychological Association became the Royal College of Psychiatrists, wisely the motto Let Wisdom Guide was chosen, wisdom being defined as an "ability to think and act utilising knowledge, experience and understanding, common-sense and insight".

Such wisdom was therefore both a science and an art: it was a mind odyssey.

Professor Cox hoped his report had shown that wisdom in its fullest sense nurtured by his predecessors was still present in the here and now, and would, he was sure, follow us into the next College year - and beyond.

\section{References}

COX, J. (2001) Corridors of power? College News, 12, $1-2$

OATES, M. (2000) Perinatal Maternal Mental Health Services. Council Report CR88. London: Royal College of Psychiatrists.

ROYAL COLLEGE OF PSYCHIATRISTS (2000) Good Psychiatric Practice. Council Report CR83. London: Royal College of Psychiatrists.

-(2001a) Community Care. Council Report CR86. London: Royal College of Psychiatrists.

- (2001b) Roles and Responsibilities of a Consultant in Adult Psychiatry. Council Report CR94. London: Royal College of Psychiatrists (in press).

- (2001c) Report of the Ethnic Issues Project Group. Council Report CR92. London: Royal College of Psychiatrists (in press).
- ROYAL COLLEGE OF PHYSICIANS OF LONDON \& BRITISH MEDICAL ASSOCIATION (2001) Mental Illness: Stigmatisation and Discrimination within the Medical Profession. Council Report CR91. London: Royal College of Psychiatrists, Royal College of Physicians of London \& BMA.

ROYAL COLLEGE OF PSYCHIATRISTS WORKING PARTY (2001) Guidelines for Researchers and for Research Ethics Committees on Psychiatric Research Involving Human Participants. Council Report CR82. London: Gaskell.

\section{Treasurer's report}

The Treasurer presented a brief report, as members had already received a copy of her formal Report, together with a summary of the accounts. Both had already been approved by the Executive and Finance Committee, Council and the auditors.

The Treasurer reported that the College's largest source of income came from members' subscriptions, so it was a cause of satisfaction that the membership had increased to over 10000 . However, in 2000 there was a less good climate for investment and for fundraising and, as a result, the surplus was less than for the previous year. None the less, many worthwhile activities and developments had been supported, in line with the College's charitable objectives. Next year, more equitable tiered subscription rates would be introduced for overseas members and for those with reduced incomes for reasons such as taking maternity leave or working part-time.

The Treasurer stated that she aimed to make the College's income and expenditure as transparent as possible, which she hoped would be helpful to members.

Finally, in response to a question concerning the surplus made by the Examinations Department, the Treasurer confirmed that this was a very well run Department, which set budgets with appropriate prudence, but which could not be certain in advance of numbers of applicants. However, if (as last year) a modest surplus was made, the College was discussing with the trainees how this could be used to benefit both the examination system in general and the trainees themselves.

\section{Resolution}

The following resolution was proposed by Professor Robin Jacoby and seconded by Dr James Birley: "Bearing in mind the available evidence that political dissidents in The People's Republic of China (PRC) are being systematically detained in psychiatric hospitals, we propose that the Royal College of Psychiatrists takes the following action: (1) to join with the WPA to arrange a fact-finding visit to the PRC; and (2) if this visit and other evidence 
confirm political abuse of psychiatry, to ask the WPA to reconsider the constituent membership of the Chinese Society of Psychiatrists."

An additional paragraph ("(3) the College will commit itself to work with the Chinese Society of Psychiatrists to advance psychiatry and its practices in PRC to be ethically sound and evidencebased") was proposed by Dr E. Chiu, but was not seconded.

Following further discussion, an additional paragraph was proposed by Professor C. Katona and seconded by Professor C. Allwood: "(3) to work with the WPA to provide support for those Chinese psychiatrists who are committed to ethical and evidence-based practice." This was supported by an overwhelming majority.

The following amendment to paragraph (2) was proposed by Dr R. Brahma and seconded by Dr R. Lutchman: "if this visit and other evidence confirm widespread political abuse of psychiatry, to ask the WPA to reconsider the constituent membership of the Chinese Society of Psychiatrists". This amendment was defeated by a large majority.

A vote was then taken on the original resolution and the additional third paragraph: "Bearing in mind the available evidence that political dissidents in The People's Republic of China (PRC) are being systematically detained in psychiatric hospitals, we propose that the Royal College of Psychiatrists takes the following action: (1) to join with the WPA to arrange a fact-finding visit to the PRC; (2) if this visit and other evidence confirm political abuse of psychiatry, to ask the WPA to reconsider the constituent membership of the Chinese Society of Psychiatrists; (3) to work with the WPA to provide support for those Chinese psychiatrists who are committed to ethical and evidence-based practice." This was carried by an overwhelming majority.

\section{Election and introduction of Honorary Fellows}

The following were unanimously welcomed to the Honorary Fellowship.

\section{The Lord JohnThomas \\ Alderdice}

\section{(introduced by DrJ. Calvert)}

President, it is a great pleasure and honour for me to present for Honorary Fellowship of the Royal College of Psychiatrists a fellow Ulsterman, Dr John Thomas Alderdice, the Right Honourable Baron Alderdice of Knock.

John Thomas Alderdice was born in Northern Ireland on 28 March 1955, the eldest son of Reverend David and Mrs
Helena Alderdice. He was educated at primary schools in County Armagh and Belfast, and later Ballymena Academy, where he was Deputy Head Boy. In 1973 he read medicine at The Queen's University of Belfast, graduating MBBCh, BAO in 1978. In 1983 he became a Member of the Royal College of Psychiatrists (MRCPsych). This was followed by higher specialist training in psychoanalytic psychotherapy. In 1988 he was appointed by the Eastern Health and Social Services Board as Ireland's first consultant psychotherapist.

From 1991 to 1999 he was appointed an Honorary Lecturer (subsequently Senior Lecturer) in the Faculty of Medicine, at The Queen's University of Belfast teaching psychotherapy. In 1991 he was appointed the first Director of the Northern Ireland Institute of Human Relations, a position he held until October 1994. From 1993 to 1997 he served as Executive Medical Director of South and East Belfast Health \& Social Services Trust.

In 1997 he was elected a Fellow of the Royal College of Psychiatrists (FRCPsych). This was followed by his appointment in 1999 as Honorary Professor in the Faculty of Medicine, University of San Marcos, Lima. The following year he was appointed an Honorary Member of the Peruvian Psychiatric Association. Lord Alderdice joined the Alliance Party in Northern Ireland in 1978, and in October 1987 he was elected as Leader of the Alliance Party. This was followed by election to Belfast City Council in 1989 and reelection in 1993 with the largest vote of any candidate in Northern Ireland in that election.

From 1991 to 1998 Lord Alderdice led the Alliance Party delegation at the various inter-party and intergovernmental talks in Belfast, London and Dublin on the future of Northern Ireland. In 1994 he lead the Alliance Party into the Forum for Peace and Reconciliation, which was established by the Irish Government and took place at Dublin Castle. In political terms this was significant since the Alliance Party was the only non-nationalist party attending.

He had the privilege of becoming the first non-nationalist party leader to attend the White House for the annua St Patrick's Day celebrations in 1995. Frequent visits continue to cement the US and Northern Ireland relationships. Lord Alderdice was elected in 1996 to the new Northern Ireland Forum leading the Alliance Party delegation in the multi-party talks chaired by Senator George Mitchell.

John Alderdice was raised to the Peerage as Baron Alderdice of Knock in 1996. He took his seat in the House of Lords on 5 November of that year, being one of the youngest ever Life Peers. He plays a significant role in the Irish Peace Process, and was one of the key negotiators of the Belfast Agreement signed on Good Friday 1998. Lord Alderdice remains a committed internationalist. He was elected Treasurer and then, in 1999 Vice-President of the European Liberal Democratic and Reform Party. In October 2000 he was elected Deputy President of Liberal International, the world wide federation of some 90 Liberal political parties.

Following his election in 1998 as a member for Belfast East, in the new Northern Ireland Assembly established by the Irish Peace Process, he stood down as Alliance Leader after 11 years in that position. He was immediately appointed Speaker of the new Assembly. His contribution to peace has been recognised through a number of international awards, including Honorary Citizenship of the City of Baltimore (1991) and Honorary Fellowship of the Royal College of Physicians of Ireland (FRCPI, 1997). He was a recipient, jointly with the former President Bill Clinton and other signatories of the Belfast agreement, of the WA Harriman Award for Democracy (Washington, 1998) and, with Senator George Mitchell and other signatories of the Belfast agreement, the John F. Kennedy Profiles in Courage Award (1998). He also received the Silver Medal of the Congress of Peru (1999), and Medal of Honour of the College of Medicine of Peru (1999).

Outside psychiatry and politics Lord Alderdice has travelled widely through his involvement in national and international religious organisations. He has helped to found a number of Northern Ireland charities and professional organisations and is patron to a number of national health care charities.

Mr President, I have the honour to present for the distinguished award of Honorary Fellowship of the Royal College of Psychiatrists, Dr JohnThomas Alderdice, The Right Honourable, Baron Alderdice of Knock.

\section{ProfessorTom Arie \\ (introduced by DrA. Fairburn)}

Professor Tom Arie can truly be described as one of the founding fathers of old age psychiatry. He created an innovative service at Goodmayes Hospital in Essex from 1969 before moving on to the Chair of Health Care of the Elderly at Nottingham University in 1997. Throughout his entire career he has been such an enthusiastic champion of old age psychiatry that there are now literally dozens of consultants in old age psychiatry who were trained by him. Arguably this is the greatest testimony of all. 